\title{
Discerning Public Policy in Public Liability A Comparative Analysis of French and Danish Law
}

\author{
Holle, Marie-Louise
}

Document Version

Final published version

Published in:

Revue Internationale de Droit Compare

\section{Publication date:}

2016

\section{License \\ Unspecified}

Citation for published version (APA):

Holle, M-L. (2016). Discerning Public Policy in Public Liability: A Comparative Analysis of French and Danish Law. Revue Internationale de Droit Compare, (3), 723-742.

Link to publication in CBS Research Portal

\section{General rights}

Copyright and moral rights for the publications made accessible in the public portal are retained by the authors and/or other copyright owners and it is a condition of accessing publications that users recognise and abide by the legal requirements associated with these rights.

Take down policy

If you believe that this document breaches copyright please contact us (research.lib@cbs.dk) providing details, and we will remove access to the work immediately and investigate your claim. 


\section{Discerning Public Policy in Public Liability: A Comparative Analysis of French and Danish Law}

\section{Marie-Louise Holle}

Journal article (Publishers version)

CITE: Discerning Public Policy in Public Liability : A Comparative Analysis of French and Danish Law. / Holle, Marie-Louise. In: Revue Internationale de Droit Compare, No. 3, 2016, p. 723-742.

Link to publisher: http://www.legiscompare.fr/

Uploaded to Research@CBS: March २०17 


\title{
DISCERNING PUBLIC POLICY IN PUBLIC LIABILITY A COMPARATIVE ANALYSIS OF FRENCH AND DANISH LAW
}

\author{
Marie-Louise HOLLE*
}

L'objectif principal de cet article est de discerner la politique publique en droit de la responsabilité administrative. Les coopérations publiques-privées sont souvent fondées sur des contrats à long terme mais ceux-ci viennent naturellement à une fin à un moment donné, et les contrats n'ont pas d'effet pour tous les problèmes juridiques qui peuvent survenir en lien avec ces coopérations. L'article traite certains des schismes importants en droits français et danois. Bien que l'étude s'axe sur le droit danois, l'analyse inclut aussi le droit norvégien. Une question importante est de savoir si les autorités publiques sont soumises à une responsabilité stricte ou si les circonstances particulières dans lesquelles les autorités fonctionnent appellent à une responsabilité atténuée. La question de la distribution des pertes est également étudiée. D'une part, si l'État indemnise les pertes que subissent les citoyens, les montants sont "pulvérisés" dans la vaste économie de l'État. D'autre part, il y a aussi des arguments convaincants pour la limitation de la responsabilité administrative.

The main focus of this article is to discern public policy in public liability law. Public-private cooperation is often based on long-term contracts, but they naturally come to an end at some point in time, and contracts do not have effect for all legal problems public-private cooperations may give rise to. The article addresses some notable schisms in Danish and French law. While the focus is Danish law, the article also includes Norwegian law. The article analyses whether public authorities must live up to strict liability, or whether the special circumstances in which authorities navigate call for a mitigated liability. Loss distribution is also addressed. On one hand, if the state compensates the citizens' losses, the amounts are being "pulverised" in the vast state economy. On the other hand, there are also strong arguments for limiting public liability.

\footnotetext{
${ }^{*}$ Associate Professor, PhD, DESS, Law Department, Copenhagen Business School.
} 


\section{POLICY MATTERS IN PUBLIC LIABILITY}

Public-private cooperation (outsourcing, contracting out, public-private partnerships etc. $)^{1}$ are often seen as a new way for the State to provide services. However, in a context of European history, public-private cooperation has been known for centuries, if not for millennia. In ancient Rome, various contracts were used by the Empire and the municipalities. There were contracts with private parties on roads, thermal baths, markets and harbours. In France, in as early as the 17th century, King Henri IV ${ }^{2}$ entered into contracts with private parties in order to ensure that certain public functions were carried out; cleaning and paving of the streets were done by private companies. The contracts were executed with much success. ${ }^{3}$ In spite the fact that public-private cooperation go back so far in time, and probably causing damages along the way, public liability has a much shorter story, and we have yet to see liability in connection with public-private cooperation in Denmark. However, this will surely come, given the global success of public-private cooperation, and given the growing tendency of citizens complaining and claiming compensation from public authorities. If one searches for statutory rules or an actual legal doctrine on public liability for private parties, one will often search in vain, despite the long history, as not many cases have arisen, and the doctrine is relatively undeveloped.

The purpose of this article is to contribute to the development of legal theory by pointing out the policy concerns and by analysing the scarce legal theory on the public secondary liability for private contractors. By virtue of

1 F. BEZANÇON and others, Le guide opérationnel des PPP, Direction des affaires juridiques, Les éditions de journaux officiels, 2010; F. BRENET \& F. MELLERAY, Les contrats de partenariat de l'ordonnance du 17 juin 2004, Litec, 2005; P. GONOD and others (Eds), Traité de droit administratif, t. II, Dalloz; C. GREVE \& U. MÖRTH, "Public-Private Partnerships: The Scandinavian Experience" (2010), G. A. HODGE and others (Eds), International Handbook on Public-Private Partnerships, Cheltenham, Edward Elgar; T. INDÉN \& K. O. OLESEN, Offentligprivat samarbejde, DJØF, 2012; Institut de la Gestion Déléguée Dexia, Partenariats public-privé, Mode d'emploi juridique et approche économique, La documentation Française, 2006; Institut de la Gestion Déléguée Dexia, Partenariats public-privé: Recueil des textes et de la jurisprudence applicables aux collectivités locales, La Documentation Française, 2006; P. LIGNIÈRES, Partenariats public-privé, $2^{\mathrm{e}}$ éd., Litec, 2005; C. D. TVARNØ, "Danish Public-Private Partnerships in a Comparative Perspective" (2015) Erhversretlige emner: Juridisk Institut CBS, P. ARNT NIELSEN, P. KOERVER SCHMIDT, K. DYPPEL WEBER (Eds.), DJØF, pp. 325-348; C. D. TVARNØ, "Law and regulatory aspects of public-private partnerships: contract law and procurement law" (2010) G. A. HODGE and others (Eds), International Handbook on PublicPrivate Partnerships (Cheltenham, Edward Elgar 2010); C. D. TVARNØ “Offentlig-privat partnerskab - lovregler eller politisk strategi?" U 2011B.129.

${ }^{2}$ King of France 1589-1610 (1553-1610).

${ }^{3} \mathrm{X}$. BERGĖRE and others, Le guide opérationnel des PPP, Direction des affaires juridiques, Les éditions des journaux officiels, 2010; F. BEZANCON, 2000 ans d'histoire du partenariat public-privé, $3^{\mathrm{e}}$ éd., Éditions Le Moniteur, 2010. 
the principle of privity of contract, a public-private contract does not have effects, at least not immediate, between the state and the citizens. Therefore, one must look into the other legal sources, which are the general public liability and the particular rules of liability for independent contractors.

Why is liability and public-private cooperation an interesting topic despite there being so little case law? Secondary liability is interesting, and all the more because it often arises namely in cases where the primary tortfeasor (the private contractor) is insolvable, the tortfeasor's liability is statute-barred, or if it cannot be decided which of several contractors is liable. ${ }^{4}$ Insolvability is quite a relevant case now with the financial crisis. Secondary liability is also relevant when dealing with post-contract liability.

Public activity can generate damages which can be serious and important, especially when large installations and heavy materials are used. Tort law is often seen as a mechanism allowing a negative effect to be converted into an amount of money. The ever-present problem is whether victims can expect compensation and, if so, under which conditions? Tort law is changing, both in the public sphere and in the private sphere. The past 100 years or so have been marked by an increasing focus on the individual, with responsiveness and receptiveness to the individual's rights. The consequence is that a greater number of losses are covered. Some speak also of the "socialisation of risks". In public law, changes have already come with private contractors cooperating with public authorities in solving public tasks, by way of privatisation to various extents.

In this article, comparative law is used to discern matters of legal policy. Courts take in a wide range of considerations, which are different from basic tort law. In Murphy's words, liability of public authorities (or public liability, henceforth used interchangeably) can be characterised as a "[...] tangled mess into which the law has woven itself in this field". ${ }^{5}$ There is not an abundance of case law in Scandinavia. The Danish doctrine is particularly scarce and characterised by doubt. The idea behind this article is to single out the legal policy concerns in the public liability and the secondary liability of the state for private contractors towards citizens, emphasising out the argumentation lines. Since the Danish doctrine is particularly scarce, Norwegian law is included in the analysis accordingly to principles for legal dogmatic analysis in Scandinavian legal science. ${ }^{6}$ Even though one of the main purposes of this article is to analyse Danish law,

${ }^{4}$ P. S. ATIYAH, Vicarious Liability in the Law of Torts, Butterworths, 1967; B. GOMARD, Moderne erstatningsret, DJØF, 2002.

${ }^{5}$ J. MURPHY, "The Negligence Liability of Public Authorities by Cherie Booth and Dan Squires" (2007) vol. 70, No. 2, March, The Modern Law Review, England, 339.

${ }^{6} \mathrm{~K}$. ZWEIGERT and H. KÖTZ, An introduction to comparative law, $3^{\text {rd }}$ Ed., Clarendon Press 1998; O. LANDO, Kort indføring i komparativ ret, $3^{\text {rd }}$ Ed., DJØF, 2009. 
referring to Norwegian law is useful, when one considers the common character of Scandinavian law. The legal traditions of Norway and Denmark are quite similar. ${ }^{7}$

In order to find the decisive elements in the State legal policy treatment of its citizens, first the pertinent public policy aspects of state liability are singled out. The analysis then focuses on the possibilities for the citizens to direct a claim of secondary liability towards public authorities. The last paragraph brings the article to a close by drawing some perspectives on policies in public liability.

\section{LEGAL BASES OF PUBLIC LIABILITY}

Due to the large size of the public sector and the number of different tasks incumbent on the public sector, mistakes and damages are inevitable. The growing number of risk factors have had an impact on the development of tort law rules, notably the application of strict and no-fault liability is more frequent nowadays. The particular conditions in the public sector must be taken into account. There are also procedural measures helping the plaintiff, namely the easing or even the reversal of the burden of proof. Part of the solution has been to submit more areas to no-fault liability, instead of requiring a 'faute lourde' (gross negligence).

\section{From irresponsibility to the socialisation of risk}

The maxim "the King can do no wrong" meant that public authorities were not liable in torts until the end of the $19^{\text {th }}$ Century. ${ }^{8}$ Irresponsibility was seen as the corollary to sovereignty. ${ }^{9}$ This approach was of course more acceptable 150 years ago, when there was much less focus on the individual, and on the individual's rights. One may even go as far as talking about an ideology of compensation. In earlier times, many states were more liberal in the sense that only few activities were carried out by public authorities. That meant fewer occasions for the State to cause damage..$^{10}$ In modern societies, many activities fall under the scope of public authorities. Activities are carried out in a variety of ways, many only by the public authorities, but a growing number is carried out by the authorities in cooperation with private contractors. Consciousness of compensation and "victimisation" has risen in

${ }^{7}$ K. ZWEIGERT and H. KÖTZ, An introduction to comparative law, pp. 276-285.

${ }^{8}$ V. ULFBECK, Erstatningsretlige grcenseområder, $2^{\text {nd }}$ ed., DJØF, 2010, p. 250; C. DEBBASCH and F. COLIN, Droit administratif, $10^{\mathrm{e}}$ éd., Economica, 2011, p. 456.

${ }^{9}$ P. L. FRIER and J. PETIT, Droit administratif, $8^{\mathrm{e}}$ éd., LGDJ, 2013, p. 560

${ }^{10}$ J. WALINE, Droit administratif, $24^{e}$ éd., Dalloz, 2012, pp. 483-484. 
recent decades. This is, to a certain extent, due to a mirror effect, meaning that public liability increased when private liability got a larger scope. Private liability increased in part due to insurance coverage becoming more frequent. In France, in a famous decision ${ }^{11}$ of the Tribunal des conflits, it was established that the State can indeed be held liable towards its citizens. It also follows from the Blanco case that particular rules apply to public liability in France, meaning distinct from those of private liability. ${ }^{12}$ However, regular conditions of liability, which are also present in private law, must be fulfilled. These conditions are mainly: The existence of damage, a cause and causation (the causal link between the breach of duty and the damage). There are, as always, certain exceptions for nonliability, such as force majeure in certain cases in French law, ${ }^{13}$ contributory negligence from the victim or a third party ${ }^{14}$ and acceptance of risk. ${ }^{15}$

As for the systematic approach, liability of public authorities is a sub discipline in administrative law. In both jurisdictions, rules of public liability are mainly unwritten. There is a notable material difference between French and Danish public liability law. In Danish law, the rules applied are those of general tort law, which are the same for private and public torts. In France, a distinct body of rules applies; however, public liability is influenced by civil liability to a limited degree and vice versa. ${ }^{16}$ The distinction between private and public law certainly exists in Scandinavia, but it holds a less predominant place than it does in the Roman law countries, such as France, Spain and Italy. In Danish law, while ordinary tort law rules are applicable, certain principles manifest themselves in a particular manner, taking the public sector's specific conditions into account, ${ }^{17}$ see below (2.).

It is often said of comparative legal studies that many legal results, as ultimate goals, are the same across countries, but that the mechanisms for reaching those goals are different. Both legal systems' tort law has

\footnotetext{
${ }^{11}$ Blanco, Tribunal des conflits, 8 Feb. 1873.

${ }^{12}$ C. DEBBASCH and F. COLIN, Droit administratif, p. 443; M. WALINE, Droit administratif, p. 501. On the distinction between private and public law, see J.-B. AUBY, $L a$ distinction $d u$ droit public et $d u$ droit privé: regards français et britanniques, Eds Auby \& Freedland, Editions Panthéon-Assas, 2004; D. de BÉCHILLON, Encyclopédie Dalloz, Répertoire de la Responsabilité de la puissance publique, Dalloz.

${ }^{13}$ Conseil d'État Sect. French Council of State, hereinafter cited as "CE Sect.", 29 July 1953 , Époux Glasner; Conseil d'État, Hereafter cited as "CE”, 4 April 1962, Ministère des Transports.

${ }^{14}$ CE, 4 April 2005, M. Bonnafoux.

${ }^{15}$ P. CANE, The Anatomy of Tort Law, Hart Publishing, 1997, p. 1; B. von EYBEN and H. ISAGER, Larebog $i$ erstatningsret, $7^{\text {th }}$ ed., DJØF, 2011, pp. 78-82; J. WALINE, Droit administratif, p. 492

${ }^{16}$ P. Le TOURNEAU, Droit de la responsabilité et des contrats, $\left(9^{\mathrm{e}}\right.$ éd., Dalloz, 2012, p. 118.

${ }^{17}$ V. ULFBECK, Erstatningsretlige grcenseområder, p. 249; M.-L. HOLLE « Remedying Political Risk in Public-Private Contracts » (2015) Erhversretlige emner: Juridisk Institut CBS, P. ARNT NIELSEN, P. KOERVER SCHMIDT, K. DYPPEL WEBER (Eds.), DJØF, pp. 371-385.
} 
compensation and prevention of damage as the main purposes. Most emphasis is placed on compensating the victim who has suffered damage. ${ }^{18}$

Older legal theory also mentions sanction as a purpose. The idea is (or rather was) that tort law should sanction the fact that the victim's rights had been infringed by the tortfeasor. Sanction does not appear in Danish tort law, but it appears certain places in French doctrine. ${ }^{19}$ Sanction has, generally speaking, disappeared from Danish tort law and has become less prevalent in French tort law, since the Christian conception of guilt has become less important with the appearance of secular societies. ${ }^{20}$ As previously mentioned, still more focus is placed on the victim's need for, or right to, compensation.

As a legal discipline, the liability of public authorities is characterised by a large amount of statutory law, compared to that of the private sector. Many statutory acts targeting the public sector are intended to have a regulating effect on the conduct of the public authorities. When deciding a court case of liability, the important part is deciding whether statutory law or other forms of regulation of the public sector have been breached from an objective point of view. ${ }^{21}$ In spite of the national, European and international provenance of the rules, and the quantity, none of the rules addresses public policy in this area as such, however, analysis of the rules and their application in case law allows extracting principles of public policy.

\section{Public authorities' particular (financial) conditions}

A number of particular circumstances in the public sector play a role in liability issues, both generally and in specific cases. The most important of these circumstances are addressed in the following: The difficulties of performing public tasks, the duty to act, and also act quickly, the public financial resources and the impact of the principle of separation of powers.

When examining the liability of public authorities, one often comes across the argument of public tasks being difficult to perform, and therefore

${ }^{18}$ B. von EYBEN and H. ISAGER, Larebog $i$ erstatningsret, pp. 46-55; P. L. FRIER and J. PETIT, Droit administratif, p. 559. On the relevance of prevention and compensation, see B. LIISBERG, Erstatningsansvaret for offentlig servicevirksomhet, p. 37-38; P. L. FRIER and J. PETIT, Droit administratif, p. 559; M.-L. HOLLE, Haftelsesansvaret for selvstcendigt virkende tredjemand - med scerligt henblik på offentlige opgaver, Karnov, 2013, pp. 134-135.

${ }^{19}$ P. GONOD and others, Traité de droit administratif, t. II, Dalloz, 2011, p. 653; P. L. FRIER and J. PETIT, Droit administratif, p. 559.

${ }^{20}$ P. L. FRIER and J. PETIT, Droit administratif, p. 559; M.-L. HOLLE, Haftelsesansvaret for selvstcendigt virkende tredjemcend, p. 33 with footnote 42 .

${ }_{21}$ V. ULFBECK, Erstatningsretlige grcenseområder, pp. 258-263; B. von EYBEN and H. ISAGER, Larebog $i$ erstatningsret, pp. 89-97; P. L. FRIER and J. PETIT, Droit administratif, pp. 561-562. 
gross negligence should be required to hold authorities liable. ${ }^{22}$ Court and legislators may wish not to "paralyse" public administration by imposing liability too eagerly, and instead leaving room to manoeuvre. ${ }^{23}$ In Danish theory, it is also argued that a number of tasks would not be solved had it not been for the public authorities, and this fact may mean that the standard of negligence should be less severe. Furthermore, public authorities are frequently subjected to a duty to act, which may also mean that the negligence standard becomes less severe. ${ }^{24}$ Moreover, public authorities are often obliged to act quickly, because time limits are short. ${ }^{25}$

It should be considered that the (limited) public financial resources are also quite important when analysing the legal policy in this area. The financial resources argument is interesting, because it is so important in practice and because it can go in both directions, so to speak. Considering public financial resources can on one hand mean that public authorities should cover citizens' losses to a large extent. On the other hand, the limited public funds (tax payers' money) should not be spent on paying compensation. It seems that the latter point of view has less impact in France nowadays, where it seems individual rights should not be sacrificed for public convenience. It is still rather prevalent in Denmark, where bars and limits on public liability in many cases still are seen as being in the general interest. ${ }^{26}$ Resources are very often limited in terms of personnel and finances, and that may add some to the argument of not imposing a low duty of care on public authorities. One may further argue that the limited resources should not be used to cover liability claims, especially in France and in the Scandinavian countries, where social security is wide spread. ${ }^{27}$

Opposing the general interest in sparing public funds is the so-called "pulverisation" argument. This reasoning is that the great "carrying capacity" of the state means that the amount covering the liability claim is "pulverised" in the vast, public economy. ${ }^{28}$ A strict duty of care or even a no-fault liability would cover more torts. The pulverisation argument is related to the principle of "the strongest shoulders bearing the heaviest

\footnotetext{
${ }^{22}$ P. L. FRIER and J. PETIT, Droit administratif, pp. 562-563.

${ }^{23}$ P. L. FRIER and J. PETIT, Droit administratif, p. 609.

${ }^{24}$ See Danish Supreme Court case U 1994.247 H.

${ }^{25}$ V. ULFBECK, Erstatningsretlige grcenseområder, p. 251.

${ }^{26}$ C. DEBBASCH and F. COLIN, Droit administratif, p. 44; J. JESPERSEN, Søfartsregler I $\& I I, 3^{\text {rd }}$ Ed., Karnov, 2012, p. 126.

${ }^{27}$ V. HAGSTRØM, Offentligrettslig erstatningsansvar - Studier i spesiell og alminnelig erstatningsret, TANO, 1987, p. 39; J. DIXON, "Comparative social security: "The challenge of evaluation"” (1998), 1:1, Journal of Comparative Policy Analysis: Research and Practice, 61, p. 69.

${ }^{28} \mathrm{~V}$. HAGSTRØM, Offentligrettslig erstatningsansvar, p. 37; B. LIISBERG, Erstatningsansvaret for offentlig servicevirksomhet, kritikk av en juridisk vranglare, Fagbokforlaget Gads Forlag, 2005, pp. 38-40; K. KRÜGER "Mild norm for offentlige tjenester på vei inn i rettshistorien?" (2006) Tidsskrift for erstatningsrett.
} 
burden". A Norwegian author, Liisberg, believes that the importance of the "pulverisation" argument is underrated, both in practice and in theory, ${ }^{29}$ which is probably also true for Danish law. ${ }^{30}$

In Danish law, as well as in French, the constitutional principle of separation of powers plays an important role. ${ }^{31}$ The principle of separation of powers was also discussed in the aforementioned French Blanco case. In a number of Danish cases concerning the level and quality of public services, courts have refrained from assessing the allocation of public funds to, for instance, hospital facilities and road maintenance. ${ }^{32}$ The courts have in these cases stated that allocation of funds on the public budget is subject to a political decision. When parliament has delegated discretionary power to e.g. local governments or municipalities, it is questionable, as a matter of the principle of separation of powers, if the courts should be censoring the exercising of that power. The question is therefore whether there should be any judicial intervention in the allocation of public money and the prioritization of resources. ${ }^{33}$ There is a saying in French law, "juger l'administration, c'est encore administrer", which comes to mind when looking at Danish case law. One may ask whether judges deciding a negligence case are better positioned than for instance local governments choosing proper allocation of funds on the public budget. ${ }^{34}$ So far, the Danish solution is that the courts only see to that a minimum standard is fulfilled. $^{35}$ This is especially true for hospital liability and winter maintenance of roads. ${ }^{36}$ However, case law shows that where legislation sets

\footnotetext{
${ }^{29}$ B. LIISBERG, Erstatningsansvaret for offentlig servicevirksomhet, pp. 38-40.

${ }^{30} \mathrm{~V}$. ULFBECK, Erstatningsretlige grcenseområder, p. 252; M.-L. HOLLE, Hoeftelsesansvaret for selvstondigt virkende tredjemcend, pp. 137-138.

${ }^{31} \mathrm{~V}$. ULFBECK, Erstatningsretlige grcenseområder, pp. 263-270; M.-L. HOLLE, Hoeftelsesansvaret for selvstcendigt virkende tredjemcend, pp. 137-138, 202-205.

${ }^{32}$ For instance U 1997.200 V, FED 1999.411 Ø, U 2000.651 Ø, FED $2000.651 \varnothing$, U 2000.1196 H, U 2001.101 V, U 2001.956 Ø, U 2003.2928 Ø, FED 2003.1348 H, U 2004.550 Ø, U 2010.336 Ø.

${ }^{33}$ See also U $2001.956 \varnothing$.

${ }^{34}$ N. PONTOPPIDAN, "Lageansvar - offentlige myndigheders ansvar" (U 1985B.248); M.L. HOLLE, Haeftelsesansvaret for selvstcendigt virkende tredjemaend, pp. 137, 202-205. See discussion in English law, E. BANAKAS, "Civil liability for pure economic loss" (1994) (Proceedings of the annual International Colloquium of the United Kingdom National Committee of Comparative Law held in Norwich, September, 1994), Kluwer Law, Londres, 1996.

${ }^{35}$ See Danish Supreme Court cases U 2013.2324 H, U 2012.2489 Ø, U 2009.1835 H, U 2008.2813 H, U 2000.1196/2 H, U 1985.368 H; see also U 1987.258 H; C. HENRICHSEN, Minimumsstandarder for offentlig service, in Forvaltning og retssikkerhed, P. BLUME \& C. HENRICHSEN (Eds.), 2014, DJØF, p. $177 \mathrm{ff}$.

${ }^{36}$ Danish cases U 1997.200 V, FED 1999.411 Ø, 2000.651 Ø, 2001.101 V, $2003.2928 \varnothing$, FED 2004.550 Ø, U 2004.550 Ø, FED 2005.34 V, U 2010.336 Ø; M.-L. HOLLE, Hceftelsesansvaret for selvstcendigt virkende tredjemaend, pp. 202-205.
} 
forward rather specific demands to municipal authorities, courts are less hesitant to subject public services to judicial review. ${ }^{37}$

\section{3. «Victim friendly» procedural policies}

Recently, courts have contributed to the improvement of victims' situation vis-à-vis public authorities. Rules on the burden of proof are sometimes used to achieve substantive law purposes. In some instances, applying a reversed burden of proof can in reality come close to imposing strict liability. ${ }^{38}$ Besides allocating the burden of proof to the defendant, courts have in a number of cases, where the burden of proof was not reversed, adjusted the standard of proof by lowering the level of proof. Thereby it becomes easier for the plaintiff (the victim) to meet the burden of proof. More importantly, the courts have gone as far as reversing the burden of proof in various cases. This means that negligence (on behalf of defendant, the public authority) is presumed. Then it is incumbent on the public authority to demonstrate absence of fault. This is especially seen in cases of hospital liability and the liability for public roads. ${ }^{39}$ This is of course interesting, since hospitals and roads are objects of Public-Private Partnerships. However, hospital liability is now regulated by statutory law, the Danish health service's Patient Insurance. Reversing of the burden of proof is often just a step on the way to a no-fault liability, both in Danish and in French law. ${ }^{40}$

\section{Negligence and no-fault liability}

Tort law rules are influenced by the tension between the two dominant theories, negligence and strict liability. Generally speaking, liability can be imposed either on grounds of negligence (2.4.1), or it can be imposed as strict liability (the victim has suffered a damage, but he or she need not prove negligence on the part of the tortfeasor), hence no-fault liability (2.4.2). The latter is much more current in the French regime of liability of public authorities than it is in the Danish regime.

\footnotetext{
${ }^{37}$ Regarding special needs teaching in the public schools: FED $2007.45 \mathrm{~V}$ and U 2010.1394 H; see also FED 2001.909 V; V. ULFBECK, Erstatningsretlige grcenseområder, p. 268.

${ }^{38}$ V. ULFBECK and M.-L. HOLLE, "Tort Law and Burden of Proof: Comparative Aspects. A Special Case for Enterprise Liability?" (2009) European Tort Law 2008, Springer, p. 26.

${ }^{39}$ R. CHAPUS, Droit administratif general, t. I, $15^{\mathrm{e}}$ éd., Montchrestien, 2001, pp. 1355-1356; B. von EYBEN and H. ISAGER, Lcerebog $i$ erstatningsret, pp. 168-169; P. L. FRIER and J. PETIT, Droit administratif, pp. 572-573.

${ }^{40}$ B. von EYBEN and H. ISAGER, Larebog i erstatningsret, pp. 168-169; P. L. FRIER and J. PETIT, Droit administratif, p. 573.
} 


\section{a) Liability for negligence}

The main rule in both French and Danish law is fault-based liability, meaning that the tortfeasor must have committed a fault or acted negligently. This holds true, even if strict liability is becoming more important in French law. ${ }^{41}$ A simple fault is enough; however, gross negligence is still required in many areas in Danish law, and, in some areas, in French law. ${ }^{42}$ Therefore, the duty of care is quite variable in both French and Danish law, depending on the specific area. Only a low duty of care is owed for control activities in France and in Denmark. ${ }^{43}$ Generally, only serious fault is sanctioned in French law. ${ }^{44}$ In Denmark, various control activities are now carried out by private companies.

As for the definition of fault and negligence, the Danish judge only has very general norms at his or her disposition. The French judge does not have general norms as such to his or her disposition. The judge, in either country, appreciates the case's circumstances in concreto and thereby decides whether the public authority acted negligently. The French judge and the Danish judge, respectively, consider how difficult the task was for the public authority, and whether exceptional circumstances were present in terms of time, place and/or resources (material, manpower, financial resources). This means that the evaluation is quite specific, and that the same conduct could qualify as negligent in one situation, but not in another. ${ }^{45}$ Danish case law seems to show that irresponsibility is possible, where a public activity was carried out as merely an "extra service" and not by virtue of an obligation incumbent upon the authority in question. ${ }^{46}$

Whereas the standard of care for public authorities in Danish law may in several respects be characterized as quite low, courts hold authorities to a high standard of care when it comes to giving advice/guidance ${ }^{47}$ and information ${ }^{48}$ to citizens in their individual capacity (not the general public).

\footnotetext{
${ }^{41}$ C. DEBBASCH and F. COLIN, Droit administratif, p. 453.

${ }^{42}$ On the concept of fault, see e.g. P. L. FRIER and J. PETIT, Droit administratif, p. 563; V. ULFBECK, Erstatningsretlige grcenseområder, pp. 273-274.

${ }^{43}$ B. LIISBERG, Erstatningsansvaret for offentlig servicevirksomhet, pp. 347-61; V. ULFBECK, Erstatningsretlige grcenseområder, pp. 258-263; J. WALINE, Droit administratif, pp. 510-512; P. L. FRIER and J. PETIT, Droit administratif, p. 571.

${ }^{44}$ P. L. FRIER and J. PETIT, Droit administratif, p. 571.

${ }^{45}$ J. WALINE, Droit administratif, p. 506.

${ }^{46} \mathrm{U} 2002.333 \mathrm{H}$ and U 1989.637 SH; V. ULFBECK, Erstatningsretlige grcenseområder, p. 270.

${ }^{47}$ U 2004.2244 H, U 1996.1288 V and U 1990.263 Ø; V. ULFBECK, Erstatningsretlige grcenseområder, p. 271.

${ }^{48}$ U 2010.399 V, U 2003.1366 V and U 1995.247 V; V. ULFBECK, Erstatningsretlige grcenseområder, pp. 271-272.
} 
The standard of care is often said to be comparable to that of professionals such as lawyers. ${ }^{49}$

\section{b) Strict liability}

In French law, strict liability can be imposed either on the basis of the principle of equality before public charges, or on the basis of liability for risk. Strict liability is in the victim's interest, as strict liability ensures that losses are compensated, regardless of negligence. The victim only needs to prove a causal link between the damage and the public activity. ${ }^{50}$ The number of particular regimes based on strict liability is increasing in French law according to several authors. ${ }^{51}$ French administrative courts have shown a relatively great willingness to impose strict liability. Strict liability is not frequent in Danish law. ${ }^{52}$ Furthermore, this basis of liability has not been adopted by the Court of Justice of the European Union. ${ }^{53}$ Therefore, this paragraph is mainly about French law.

Strict liability, also called absolute liability or no-fault liability, is the legal responsibility for damages, regardless of whether the person found strictly liable had acted negligently. In most jurisdictions, strict liability is applied to certain dangerous activities. Strict liability means that the victim does not have to prove negligence for damages caused by inherently dangerous things and operations. In many jurisdictions, this covers explosives, weapons and wild animals. In addition, for reasons of public policy, certain activities are only allowed if the person carrying them out insures others against the harm coming from the risks that the activities create. That could for instance be the use of cars and nuclear installations.

The main headers of strict liability for public authorities are the following: 1. liability for damage caused by public works to third parties (excluding users, as French law distinguishes between users and third parties) $;{ }^{54}$ 2. liability for damage suffered by public service agents (even of an occasional nature) during their work for the public service; 3. liability for damage caused by installations, property or activities which create exceptional danger, including certain damages at public hospitals; 4 . liability for damage caused by national and international legislation, lawful

\footnotetext{
${ }^{49}$ See also U 1996.1554 H; M.-L. HOLLE, Hoeftelsesansvaret for selvstcendigt virkende tredjemcend, pp. 138-139.

${ }^{50}$ C. DEBBASCH and F. COLIN, Droit administratif, pp. 461-462.

${ }^{51}$ P. GONOD and others, Traité de droit administratif, p. 637; J. WALINE, Droit administratif, p. 531 .

${ }_{52}$ B. von EYBEN and H. ISAGER, Larebog $i$ erstatningsret, pp. 161-163.

${ }^{53}$ Cases 20/06 and C-121/06 FIAMM and Fedon v Council and others [2008] ECJ.

${ }^{54}$ C. DEBBASCH and F. COLIN, Droit administratif, p. 463.
} 
administrative decisions and actions. In connection with public-private cooperation, the first form about public works (1) is the most interesting.

All the headers have in common that the victim must show that he or she was in an exceptional position. That requirement is in certain cases precisely defined (as is the case with exceptional impact of public works), or it may simply constitute a direct application of the principle of equality before public burdens. Compensation of abnormal damages is tied to this principle, as it is a requirement that the damage is abnormal. ${ }^{55}$ This means that the damage should exceed inherent inconveniences with public service, meaning that inconveniences that one ordinarily finds in public service are excluded from compensation. ${ }^{56}$

Equality before public charges ("responsabilité pour rupture de l'égalité devant les charges publiques") is a French maxim inferring liability for loss caused by the unequal operation of an administrative measure, statute law, administrative operations and permanent damages of public works. ${ }^{57}$ It appears in Article 13 of the Declaration of the Rights of Man from 1789 . The principle has constitutional value. ${ }^{58}$ Only special, abnormal damage can be claimed. The difference between this principle and the principle of liability for risk is that equality before public charges does not have the character of accidents. Equality before public charges is about natural, foreseeable consequences of public activity. Equality as an argument is (surprisingly) rarely seen in the Danish doctrine about public liability, but it appears in Norwegian theory. ${ }^{59}$

The header "public works" is particularly interesting. The idea is that public activities are carried out in the interest of everyone in society. If damages resulting from these actions were not to be compensated, the victims would be sacrificed for society, and this is unjustified discrimination. ${ }^{60}$ This consideration plays a significant role in public liability, but it is far from the only ground for public liability. ${ }^{61}$ The Council of State imposes liability for abnormal risks to neighbours. This resembles the principle of private nuisance, so in this respect the public liability is comparable to Danish law. ${ }^{62}$ Neighbours to public works will often

${ }^{55}$ CE, 27 June 2005 SA Vergers d'Europe. R. CHAPUS, Droit administratif général, p. 1364; J. WALINE, Droit administratif, p. 493.

${ }^{56}$ P. L. FRIER and J. PETIT, Droit administratif, p. 579.

${ }^{57}$ P. Le TOURNEAU, Droit de la responsabilité et des contrats, pp. 480-481; P. L. FRIER and J. PETIT, Droit administratif, p. 581.

${ }^{58}$ R. CHAPUS, Droit administratif général, p. 1364; P. Le TOURNEAU, Droit de la responsabilité et des contrats, p. 125.

${ }^{59}$ B. LIISBERG, Erstatningsansvaret for offentlig servicevirksomhet, pp. 38-40.

${ }^{60} \mathrm{CE}$, Société anonyme des produits laitiers La Fleurette, 14 January 1938.

${ }^{61}$ P. Le TOURNEAU, Droit de la responsabilité et des contrats, p. 126; P. L. FRIER and J. PETIT, Droit administratif, p. 581.

${ }^{62}$ B. von EYBEN and H. ISAGER, Larebog i erstatningsret, pp. 177-178. 
experience various inconveniences due to the fact that they live nearby, and victims can sue public authorities for damages. ${ }^{63}$ The risks come in various forms, ranging from compensation of the depreciation of values of buildings situated near motorways ${ }^{64}$ to compensation in a case where game (for hunting) decreased in number when a road was carried through the plaintiff's property. ${ }^{65}$ The condition for liability is that the inconvenience(s) exceed(s) what can normally be expected.

Imposing strict liability on the tortfeasor/the liable party is at first glance a burden, as it becomes very difficult, if not impossible, to escape liability. Obviously, it is an advantage for the victim, as he or she need not work through the hierarchy of public service in order to identify the wrongdoer and the person or entity that is able to control the wrongdoer's acts. Surprisingly, strict liability may have an advantage. The advantage is that it is not necessary to demonstrate negligence, which may otherwise have disadvantageous consequences for the party at fault. The finding of gross negligence may have a very damaging effect on a professional's reputation.

\section{The rise of government-funded compensation schemes}

The "trend" of socialisation of risk also manifests itself in the existing government-funded compensation schemes ${ }^{66}$ These are automated regimes, whereby compensation is accelerated and almost automated. The fact that the State (the public fund) compensates the damage is not liability strictu sensu. ${ }^{67}$ These compensation schemes are more similar to insurance schemes, than they are to an application of tort law rules. The reason for this difference is that the victims only need to demonstrate that they have suffered damage (a loss) in a certain period of time and under certain circumstances.

Public authority actions like the compensation schemes are a matter of political choice rather than law. In practice, these schemes are probably also highly motivated by public opinion and/or political pressure. With these regimes, one wishes to erase the damaging effects of incidents, which are considered to be dramatic, and where it would be unequal to place the burden on a few citizens. Both in Denmark and France, contaminated blood led to a number of patients getting infected by HIV. Therefore, both countries created automatic schemes in order to compensate the patients,

\footnotetext{
${ }^{63}$ P. L. FRIER and J. PETIT, Droit administratif, pp. 574-588.

${ }^{64}$ CE, 22 Oct. 1971, Époux Blandin.

${ }^{65}$ CE, 19 Mar. 1975, Consorts Stem.

${ }^{66}$ J. WALINE, Droit administratif, p. 483; P. Le TOURNEAU, Droit de la responsabilité et des contrats, p. 239.

${ }^{67}$ P. GONOD and others, Traité de droit administratif, p. 638.
} 
together with a number of other countries. ${ }^{68}$ Mrs Dufoix, then Minister of Social Affairs stated the following about the affair: "liable but not guilty". 69 Other examples are compensation for victims of asbestos, nuclear tests, terrorism and violence. ${ }^{70}$

\section{PUBLIC AUTHORTIES' VICARIOUS LIABILITY FOR PRIVATE CONTRACTORS}

The purpose of the third part of the present article is to examine to which extent public authorities are vicariously liable for private contractors, who perform public activities within the framework of public-private cooperation. In general, citizens have very little direct impact on how contracts are carried out. As mentioned in the introductory part of this article, the question of vicarious liability (liability for the acts of others) is of crucial importance, especially when the private contractor is insolvent. Therefore, citizens' rights to compensation for their losses are quite important.

It goes for both Danish and French law that public authorities may be held directly liable if they have committed a fault themselves or if the authorities are otherwise liable for a situation that has caused damage, according to the rules referred to above. ${ }^{71}$ However, the conditions as to vicarious liability are different. As we will see in the following sections, the contents and effects of the Danish rules are very uncertain, whereas the French rules are quite clear in imposing vicarious liability on public authorities.

\section{The scope of liability in Danish law is uncertain}

The traditional point of view in Scandinavian law is that the "independent contractor defence" is applicable, meaning that public authorities are not vicariously liable for independent contractors towards citizens. $^{72}$ Again, the question is whether the state may become liable if the private contractor cannot cover the claim. While the independent contractor

${ }^{68}$ D. KIRP, "Look back in anger: Hemophilia and aids activism in the international taintedblood crisis" (1999) Journal of Comparative Policy Analysis: Research and Practice, 1:2, 177.

${ }^{69}$ Statement on France's national television made in November 1991.

${ }^{70} \mathrm{~A}$. FRANK, Le droit de la responsabilité administrative à l'épreuve des fonds d'indemnisation, L'Harmattan, 2008; B. von EYBEN and H. ISAGER, Lerebog $i$ erstatningsret, pp. 373-408; J. MOREAU, "La responsabilité administrative", Traité de droit administratif, t. II, Eds P. GONOD, F. MELLERAY, F. YOLKA, Dalloz, 2011.

${ }^{71}$ CE Sect., 19 Dec. 1962, Établissement Delannoy. C. DEBBASCH and F. COLIN, Droit administratif, p. 478.

${ }^{72}$ Exempting certain cases of public-private cooperation in Swedish law. 
defence holds true in the major part of private law, this may not hold true for activities that are only performed by public authorities. In private law, the exceptions are mainly damages related to roads, liability for damages caused by excavation, liability of organisers of festivals etc. and in quite exceptional cases also damages related to property and where damage is caused to neighbours' properties. ${ }^{73}$

It seems that the doctrine of nondelegable duties (also known in Common law jurisdictions) is only discussed in very few works in Danish law. Nondelegable duties are duties for which liability cannot be delegated. In recent studies, authors argue that there may be such nondelegable duties, for which the public authorities cannot delegate liability. ${ }^{74}$ The argumentation is in short that public authorities act on two different fields, seen from a tort law perspective. The first field is the so-called "common field" comprising activities which are common to public and private contractors. That could, for instance, be transportation and winter maintenance of roads. The second field is the "exclusive field", in the sense that the activities in the exclusive field are those performed only by public authorities. ${ }^{75}$ That could for instance be the operation of prisons. Due to the particular nature of the "exclusive field", the independent contractor defence does not apply.

There are some indications in both Norwegian and Danish (private) law that a range of reoccurring elements do play a role, when courts determine whether or not a principal should be held vicariously liable for damage caused by his or her independent contractor ${ }^{76}$ Even though there are few cases, all related to private contracts, it is possible to discern a number of reoccurring, decisive elements. The elements that can contribute to courts imposing vicarious liability are:

- financial circumstances, in the sense that if the principal is affluent, the courts have stated on various occasions that the principal had the opportunity to include the liability risk in his or her costs,

- the possibility of the principal to instruct, control and supervise the independent contractor to a certain degree,

${ }^{73}$ B. von EYBEN and H. ISAGER, Lcerebog i erstatningsret, pp. 177-178.

${ }^{74}$ P. GERMER, Statsforfatningsret, $3^{\text {rd }}$ Ed., DJØF, 2001, p. 87; O. FRIIS JENSEN, "Offentligretligt erstatningsansvar" (2009), J. GARDE and others (Eds), Forvaltningsret Almindelige emner, 5th ed., DJØF, 2009, 548; B. von EYBEN and H. ISAGER, Larebog $i$ erstatningsret, p. 85; M.-L. HOLLE, Hceftelsesansvaret for selvstcendigt virkende tredjemcend, pp. 171-173, 181-187.

${ }^{75}$ M.-L. HOLLE, Haeftelsesansvaret for selvstcendigt virkende tredjemaend, pp. 128-131.

${ }^{76}$ B. ASKELAND, Erstatningsrettslig identifikasjon, Cappelen Akademisk Forlag, 2002, p. 144; M.-L. HOLLE, Hoftelsesansvaret for selvstcendigt virkende tredjemaend, pp. 97-102, 106109. 
- some degree of negligence, as it appears from case law that negligence should indeed be present, either committed by the independent contractor or by the principal,

- the principal having professional knowledge of the tasks delegated to the independent contractor.

There is at present a lack of Scandinavian case law on liability and public-private cooperation. It is presently not possible to say with certainty whether these elements would also apply in cases of public-private cooperation, but it is quite likely that there will be a spill-over effect. As we shall see below, some of these conditions also appear in French law.

Some authors believe that it should be sufficient that public authorities have made careful arrangements for the public-private cooperation and thereby going against the idea on nondelegable duties. Protecting public interest is, according to some, done by barring citizens from holding public authorities vicariously liable for private contractors. This way, public funds are not used to cover damage claims. One could argue that it may be in the public interest to cover damages caused by private contractors carrying out public activities.

In another Scandinavian jurisdiction, namely Swedish law, the solution is much clearer, since public authorities are liable for private contractors carrying out activities of public power by virtue of statutory law. ${ }^{77}$

\section{Certainty: French case law maintaining vicarious liability}

The legal conditions of public authorities' vicarious liability for private contractors are quite clear in France. A private contractor who manages a public service is considered liable of that public service. ${ }^{78}$ In case the private contractor is insolvent, the public party is secondarily liable and must compensate the victim. ${ }^{79}$ This is where French law is quite different from Danish (and also Norwegian) law, being so clear about the victim's right to compensation. $^{80}$

This means that public authorities can be held vicariously liable for damages caused by pupils in the education system, for instance when there is a lack of surveillance. This holds true even when the education is carried

\footnotetext{
${ }^{77}$ The Swedish Tort Act, $3^{\text {rd }}$ Chapter, Article 2 (Skadeståndslagen 3 kap 2 §); on Swedish law, see for instance H. ANDERSSON, "Kvalificerande kriterier för myndighetsansvaret" (2008) November, Pointlex and H. ANDERSSON, Ansvarsproblem i skadeståndsrätten (Iustus Förlag 2013), p. $339 \mathrm{ff}$.

${ }^{78}$ CE, 9 May 1984, Petit.

${ }^{79}$ CE, 21 Mar. 1980, Vanderiele. Also Bureau Veritas, CE, 23 Mar. 1983. C. DEBBASCH and F. COLIN, Droit administratif, p. 478.

${ }^{80}$ P. L. FRIER and J. PETIT, Droit administratif, p. 564.
} 
out by a private contractor. ${ }^{81}$ The case of penitentiary facilities is interesting. Before gross negligence was a condition both where hospital liability and prison liability were concerned. ${ }^{82}$ Now, a simple fault is sufficient. This has in practice concerned the case where prisoners commit suicide. The penitentiary facilities have a duty to survey the prisoners. ${ }^{83}$ "Prisons without bars" and education assistance for underage criminals, as well as damages caused by evading young criminals are submitted to strict liability. ${ }^{84}$ This also goes for underage criminals placed in an authorised, private establishment. ${ }^{85}$ The same goes for an underage person in danger, who is placed in care, and suffers damage, even though this is not a case of "dangerous things" as such. ${ }^{86}$ Damages caused by prisoners on leave are also subject to strict liability, ${ }^{87}$ also for trial leave, and even for psychiatric patients. ${ }^{88}$ Hospital liability does in certain cases give rise to strict liability. ${ }^{89}$ The same goes for emergency services in France. ${ }^{90}$

A Council of State decision from 1983 is quite clear in stating the motives of public authorities' vicarious liability. The decision was about Bureau Veritas, a private ship classification society carrying out public activities of control. The Council of State held that public authorities are vicariously liable for Bureau Veritas for the following reasons: ${ }^{91}$

1) the private contractor (Bureau Veritas) carries out of public activities,

2) the private contractor is vested with authority-like prerogatives,

3) the private contractor acts on behalf of public authorities, and

4) the private contractor acts within the control of public authorities.

${ }^{81}$ Tribunal des conflits, 19 Nov. 2001, Époux Gracia. J. WALINE, Droit administratif, p. 526.

${ }^{82}$ See for instance CE Sect., 3 Oct. 1958, Rakotoarivony.

${ }^{83}$ For illustration CE, 23 May 2003, Mme Chabba; CE, 17 Dec. 2008, Zaouiya. The requirement of a simple fault also goes for damages to the prisoners' property, CE, 9 July 2008, Garde de Sceaux/M. Boussouar; see J. WALINE, Droit administratif, pp. 508-509; P. L. FRIER and J. PETIT, Droit administratif, pp. 565-566. p. 575 .

${ }^{84}$ See also CE, Sect., 3 Feb. 1956, Thouzelier, P. L. FRIER and J. PETIT, Droit administratif,

${ }^{85}$ CE, Sect., 19 Dec. 1969, Ets. Delannoy, C. DEBBASCH and F. COLIN, Droit administratif, p. 464.

${ }^{86}$ CE, Sect., 11 Feb. 2005, GIE Axa Courtage, C. DEBBASCH and F. COLIN, Droit administratif, p. 464.

${ }^{87}$ For instance CE, Sect., 2 Dec. 1981, Ministère de la Justice/Theys.

${ }^{88}$ CE, Sect., 13 July 1976, Département de la Moselle, C. DEBBASCH and F. COLIN, Droit administratif, p. 464

${ }^{89}$ P. L. FRIER and J. PETIT, Droit administratif, p. 565. 458,461

${ }^{90}$ CE, 20 June 1997, M. Theux, C. DEBBASCH and F. COLIN, Droit administratif, pp. 457-

${ }^{91}$ See also CE, 13 Mar. 1998, Améon. 
These arguments resemble those found in Danish theory, but which we have yet to see applied by the courts.

In the particular case of public works and public-private cooperation, the rights of the victim are even more advantageous. If the public party, as the contracting authority, has used a private contractor, both can be held liable separately or jointly; the victim has the choice. ${ }^{92}$

\section{PERSPECTIVES OF PUBLIC AUTHORITIES' LIABILITY}

Few legal areas have seen such great changes in such a short span of time as public liability. There has been a change in the perception from "the King can do no wrong" to the focus on victims' right to compensation.

There has not been a tradition of employing the term "public policy" in the analysis of public liability. It is, nevertheless, certainly possible to discern public policy by analysing the choices made by legislators and courts. As public liability mainly consists of unwritten law both in France and Denmark, courts have a more important role in policy making. Both Danish and French courts seem to be rather sympathetic towards the difficult conditions under which public authorities operate. Difficulties are most often limited to financial resources, but also scarcity of manpower and time. Courts have the opportunity of varying the duty of care, and they do make use of this competence. A prevailing point of view is that if courts allow (too) many compensation claims, public authorities will be paralysed, and that would not be in the interest of society. The main purpose of tort law is compensation, and this also holds true for public liability. One may also think that limiting the citizens' claim for damages is a public policy to the benefit of everybody in society. On the other hand, the "pulverisation" argument plays an important role in Danish and Norwegian law, taking into account the large public economy on one hand, and victims' need for compensation on the other hand. Public policy is therefore not unanimous in this domain; financial considerations can speak both for and against compensating losses. Both ideas can be said to be in the common interest of society.

Courts in Denmark apply the constitutional principle of separation of powers. Courts often abstain from second-guessing allocation of funds to activities of public services, and consequently often reject victims' claim for

${ }^{92}$ CE, Sect., 29 Jan. 1971, « Association Jeunesse et Reconstruction ». French public contracts are not just contracts, but also a way of organising public tasks. Due to the regulatory nature the contracts are seen to have, the contract allow the parties to derive rights from the contract, this is not accordance with the important principles of privity of contract (that a contract only has effect on its parties). C. DEBBASCH and F. COLIN, Droit administratif, p. 478. 
damages. This is quite a dilemma between treating public authorities like private entities for the purposes of tort law and abstaining from sanctioning choices made in democratic processes. ${ }^{93}$

Courts have also contributed to the development of procedural law, especially by reversing the burden of proof, but also by adjusting the standard of proof. Reversal of the burden of proof is often a step on the way to imposing strict liability in a given area of tort law. Dangerous things and operations often give rise to imposing strict liability or a high duty of care, both in Danish and French law. French courts have imposed strict liability for public authorities in situations where citizens have suffered abnormal and special damage. The characteristics "abnormal" and "special" must be emphasized, as strict liability is not a general "catch all" rule.

There seems to be made a certain prioritisation between the various types of damages. Public policy of both legislators and courts appears to give priority to compensation of bodily injury, as opposed to economic losses. Many of the rules of strict liability cover physical damages, and the same goes for most government-funded compensation schemes. Government-funded compensation, as opposed to case-by-case law suits, may be an efficient, quick and just mechanism for allocating compensation in case of larger-scale accidents, which have health problems and loss of lives as consequence.

The most significant difference between Danish and French law in the present analysis is the question of public authorities' vicarious liability for private contractors in the framework of public-private cooperation. French law is quite clear in giving equal protection to citizens regardless of whether the damages are caused directly by public authorities or whether they are caused by private contractors cooperating with public authorities. According to French law, the private contractor should cover the loss in the first place, and if the private contractor cannot do that, for instance due to insolvency, public authorities must cover the citizens' loss. Danish law is more uncertain; the traditional viewpoint is still that the independent contractor defence applies. One might think that the pulverisation argument will play a role. Also, the fact that the public authorities instruct and control the private contractor's activity, and considerations of nuisance and dangerous operations may also contribute to Danish courts imposing vicarious liability on public authorities.

Vicarious liability is often seen as a mechanism for allocating losses to those with "deep pockets". Vicarious liability bridges the gap between faultbased liability and liability for risk. A parallel development is seen in the civil liability, where more damages that do not have their basis in fault, are

${ }^{93}$ J. MURPHY, "The Negligence Liability of Public Authorities by Cherie Booth and Dan Squires", p. 339. 
compensated. ${ }^{94}$ The risk of damage is a loss, which should be offset against the profits of the tortfeasor (the party responsible for the accident). This is an application of the principle "cujus commodium, ejus periculum" (he, who has the advantage, has the risk). In recent Danish and Norwegian theory, some authors have applied the contract law idea to public liability, which has a more strict liability as a consequence, and also a wider application of vicarious liability. ${ }^{95}$ A proposal could be to impose vicarious liability on public authorities, in order to grant Danish citizens the same rights to compensation as the French have. Authority-based policy instruments use legislation and regulation to prescribe forms of behaviour, and the instruments can protect citizens in various ways, as well as changing behaviour in society. ${ }^{96}$

Analysing public policy in the relationship between the State and its citizens is important for the political choices in structuring privatisation contracts. In tort law, focus is as always on rights and obligations. One party's right is another part's obligation. But focus has shifted from the public authorities' rights and citizens' obligations, to public authorities' obligation and citizens' rights. The policy considerations behind public liability is not so much that all damage should be compensated, but rather that there should be efficient compensation mechanisms and allocation of financial losses. Legal dogmatism aside, there may frequently be some impact of the public opinion on legislators such as the haemophilia interest groups in some countries. ${ }^{97}$ Law and politics are inextricably linked to one another.

\footnotetext{
${ }^{94}$ C. DEBBASCH and F. COLIN, Droit administratif, p. 444.

${ }_{95}$ B. LIISBERG, Erstatningsansvaret for offentlig servicevirksomhet, pp. 56-58; V. ULFBECK, Erstatningsretlige grcenseområder, p. 252; M.-L. HOLLE, Hceftelsesansvaret for selvstcendigt virkende tredjemcend, pp. 187-189.

${ }^{96}$ Y. HAIGH, Public Policy in Australia - Theory and Practice, Oxford University Press, Australia, 2012, pp. 86-87.

${ }^{97}$ D. KIRP, "Look back in anger: Hemophilia and aids activism in the international taintedblood crisis", p. 177.
} 